\title{
Chemical and Structural Changes of Raw Phosphate during Heat Treatment
}

\author{
I.*A. Mgaidi, 'F. Ben Brahim, ${ }^{2}$ D. Oulahna, ${ }^{2}$ A. Nzihou, 'M. El Maaoui \\ ' Industrial Inorganic Chemistry Laboratory, Chemistry Department, \\ Faculty of Sciences, Tunis 1060, Tunisia. \\ ${ }^{2}$ Chemical Engineering Laboratory for Particulate Solids, CNRS UMR 2392, School of Mines of Albi- \\ Carmaux, Campus Jarlard, 81013 Albi, France.
}

(Received April 8, 2004)

\begin{abstract}
In the wet phosphoric acid production using calcined phosphate particles, physical structure and chemical composition of used material have an impact on the reaction speed.

In this study, porous properties of phosphate fraction size $125-200 \mu \mathrm{m}$ after heating at different temperature between $240^{\circ} \mathrm{C}$ to $940^{\circ} \mathrm{C}$ were investigated.

Fluorapatite, carbonate fluorapatite (Francolite), dolomite and calcite constitute the major minerals of the phosphate rock used.

The results of TG/DTA, CRTA, IR and ESEM observations were used to understand the chemical changes observed. The decline of the specific surface area (SSA) from $16.61 \mathrm{~m}^{2} / \mathrm{g}$ down to $0.81 \mathrm{~m}^{2} / \mathrm{g}$ was interpreted according to the thermal results. The increasing of the linear shrinkage $\%$ by sintering process is observed. This process begins near $240^{\circ} \mathrm{C}$ and reaches a maximum near $940^{\circ} \mathrm{C}$. These results are in agreement with those in the literature.

Some kinetic tests were undertaken at laboratory scale to elucidate the relationship between reactivity and porous properties of phosphate particles.
\end{abstract}

Key words: Phosphate ore particles, heat treatment, structural changes, sintering

\footnotetext{
•* Corresponding author : Arbi.Mgaidi@fst.rnu.tn
}

\section{INTRODUCTION}

Previous works on the calcination of calcium phosphate compounds may be classified in two categories depending on the field of interest.

The first category deals with the treatment of natural calcium phosphate to be used in the manufacture of phosphoric acid or super phosphate production. It is well known that the composition of phosphate reserves varies from one deposit to another and low grade phosphate rocks (calcareous, dolomitic, siliceous) are not usually suitable for direct use in acidulation plants. Beneficiation techniques may be applied such as calcination for the carbonate phosphate and flotation for siliceous phosphate rocks.

Calcination of phosphate rocks was proposed and used at the industry scale $/ 1,2 /$. The effect of the different experimental parameters on the beneficiation of phosphate ores by heat treatment has been considered by several authors /3-7.

Previous investigations $/ 8-10$ / successfully enriched the low-grade calcareous phosphate using heat treatment. Kaljuvee et al. /6/ proposed the calcinationseparation method for the separation of carbonaceous phosphates issues from Kazakhastan region. Zafar et al. /7/ studied in their experimental investigation, dealing with thermal beneficiation of a low grade dolomitic phosphate rock, the factors (size, temperature and time) 
affecting the increase of $\mathrm{P}_{2} \mathrm{O}_{5}$ weight $\%$ upon heat treatment.

Note that phosphate rock with a high level of organic matter can be also processed by thermal route /11\% The principal objective of such a process is the removal of the organic matter and the increase of the filtration speed of the phosphogypsium.

The second series of studies concerns applications of synthetic calcium phosphate compounds in bioceramic industry. Abadou et al. /12/ reported the influence of calcination conditions on the morphological evolution of synthetic hydroxyapatite. The calcination behaviors of pure fluorapatite and its sinterability under oxygen and argon atmosphere were studied by Ben Ayed et al. $/ 13,14 /$.

The calcination and sintering of some powders of calcium phosphate apatites with variable $(\mathrm{Ca} / \mathrm{P})$ atomic ratio were studied by Raynaud et al. /15/.

Recently some synthetic calcium phosphate compounds were tested to trap heavy metals from some industrial wastes. The resulting solids were stabilized by calcination process $/ 16,17 /$. Since then, the authors have reported some results concerning the heat treatment of pure hydroxyapatite with different $(\mathrm{Ca} / \mathrm{P})$ atomic ratio. For the synthetic calcium phosphate compounds used in bioceramic, the X-ray diffraction, thermal analysis and specific surface area determination were used.

According to our knowledge, very few experimental works devoted to the evolution of physical properties of natural calcium phosphate during heat treatment are available in the literature.

Most of the commercial phosphate rocks are of sedimentary origin and several mineralogical studies indicated that East Mediterranean and North Africa phosphorites were sedimentary deposits with francolite as the main phase. The francolite minerals have the empirical formula $\left[\mathrm{Ca}_{9.51} \mathrm{Na}_{035} \mathrm{Mg}_{0.14}\left(\mathrm{PO}_{4}\right)_{4.47}\left(\mathrm{CO}_{3}\right)_{1.26} \mathrm{~F}_{250}\right]$ which is generally accompanied by the calcite or dolomite minerals $/ 18 /$, although the choice of a technology for enrichment depends on the origin of phosphorites and on its physical and chemical properties. For Morocco or Tunisian phosphate, the flotation beneficiation results were less satisfactory and thermal methods can be more effective.

The purpose of this work was to investigate the evolution of physical properties according to the temperature of calcination of raw phosphate particles fraction $(125-200 \mu \mathrm{m})$. The chemical and structural changes were investigated using experimental techniques such as thermal analyzer (DTA-TG and CRTA), I.R spectroscopy, X-ray diffraction, true density, BET surface area and environmental scanning electron microscopy (ESEM).

\section{MATERIAL AND METHODS}

The phosphate ore used in the study was provided from the Gafsa area reserves, in Southwest Tunisia. The ore was crushed, ground and sieved to obtain the fraction size $(125-200 \mu \mathrm{m})$ using ASTM sieves. The analysis of calcium was performed using Flame Atomic Absorption Spectroscopy (FAAS) from Varian. Phosphor as the anion $\mathrm{H}_{2} \mathrm{PO}_{4}^{-}$and $\mathrm{F}^{-}$were analyzed using a Dionex ion chromatograph with ion Pac AS12A Guard Plus analytical column. The chemical analysis of the sample is reported in Table 1. This chemical composition was given as weight $\%$ in dry basis. From this analysis, we observed that the ratio $\left(\mathrm{CaO} / \mathrm{P}_{2} \mathrm{O}_{5}=1.605\right)$ is greater than the one observed for the synthetic fluoraptite $\left(\mathrm{CaO} / \mathrm{P}_{2} \mathrm{O}_{5}=1.31\right)$ and the amount of fluor found in this ore is high $(3.16 \%)$. The high fluorine content and the high ratio $\left(\mathrm{CaO} / \mathrm{P}_{2} \mathrm{O}_{5}\right)$ were attributed to the francolite and fluorapatite the main minerals of phosphate particles.

Amounts of $10 \mathrm{~g}$ of phosphate ore of the investigated fraction size were calcined in a tubular furnace, under air flow, in isothermal conditions. The treatments were carried out between 240 and $940^{\circ} \mathrm{C}$. The heating rate was of $10^{\circ} \mathrm{C} / \mathrm{min}$. from room temperature to the chosen temperature. Each sample was held for one hour at the chosen temperature and cooled at the same heating rate to room temperature. The results show that the calcination time considered was sufficient to reach thermal equilibrium corresponding to a constant weight loss. At the end of a run, the remaining solid was weighed. In these conditions, no sticking was observed at the side of the melting pot.

The investigated sample (fraction size 125-200 $\mu \mathrm{m}$ ) and the treated one at $780^{\circ} \mathrm{C}$, were examined in an Xray diffractometer using $\mathrm{CuK} \alpha$ (PHILIPS apparatus) to 
Table I

Chemical composition of the phosphate rock used.

Data* from Ben Brahim /28/'

\begin{tabular}{ccccccc}
\hline Component & $\mathrm{CaO}$ & $\mathrm{P}_{2} \mathrm{O}_{5}$ & $\mathrm{~F}^{-}$ & $\mathrm{CO}_{2}$ & $\mathrm{MgO}$ & Loss in ignition \\
\hline$\% w t$ & 44.8 & 27.9 & 3.16 & - & - & $11.5 \%$ \\
& $(47.6)^{*}$ & $(28.8)^{*}$ & - & $(5.62)^{*}$ & $(0.66)^{*}$ & - \\
\hline
\end{tabular}

identify the mineralogical constituents. The phases present were determined by comparing the patterns with JCPDS standards. The results confirm that the ore contains essentially carbonate apatite, fluorapatite, dolomite and calcite (Figure I).

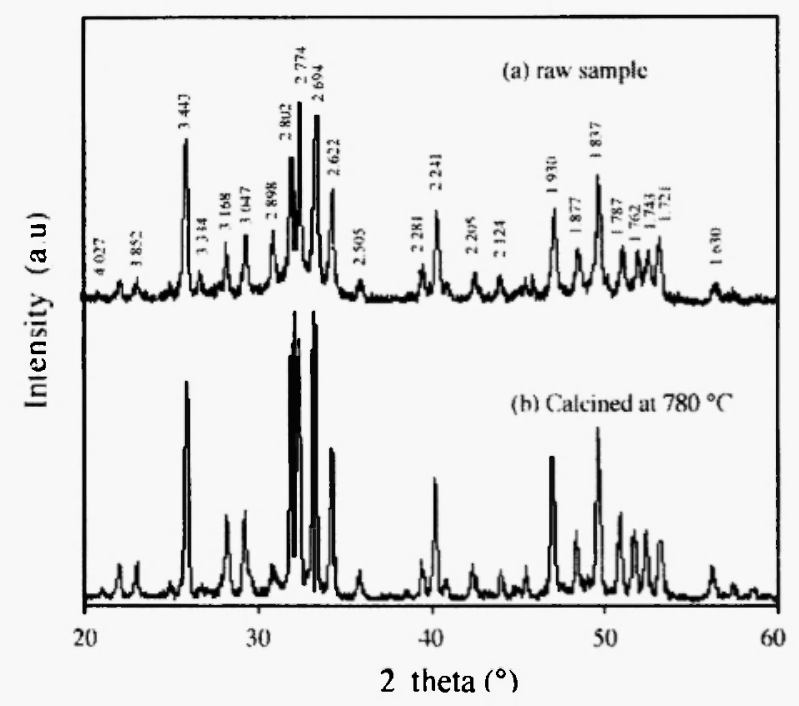

Fig. 1 : X-ray powder diffractograms of two phosphate samples: (a) raw material, (b) calcined at $780^{\circ} \mathrm{C}$

The thermogravimetric and the differential thermal analysis were carried out under argon atmosphere on 79 mg of raw material using Setaram $\circledast$ TG-DTA 12 thermal analyzer. The heating rate was $10^{\circ} \mathrm{C} / \mathrm{min}$. Controlled-transformation Rate Thermal Analysis (CRTA) was carried out using sample mass (500-1000 $\mathrm{mg})$, pressure $(3.0 \mathrm{kPa})$ and temperature rise equal to $10^{\circ} \mathrm{C} / \mathrm{min}$. This analysis was used to identify the chemical change during the heat treatment.

Samples calcined at $240,600,780$ and $940^{\circ} \mathrm{C}$ were also submitted to infrared (IR) spectrometry analysis (Perkin Elmer ${ }^{\circledR}$ ) at room temperature using $\mathrm{KBr}$ Pastilles were prepared from approximately 1 to $1.2 \mathrm{mg}$ of powder mixed with $200 \mathrm{mg}$ of $\mathrm{KBr}$ and the mixture was pressed under vacuum. A scanning rate of $40 \mathrm{~cm}^{-1}$ per minute was employed.

On the other hand, the true densities of different samples after heating at $240,400,550,600,780$ and $940^{\circ} \mathrm{C}$ were measured by volume displacement using an Accupyc®1330 Helium (Micromeritrics) pycnometer. In addition, the specific surface area was measured by BET method using $\mathrm{N}_{2}$ at $77 \mathrm{~K}$ as an adsorption gas (Micromeritics®ASAP 2000 Norcross GA).

The shrinkage tests for all raw and calcined samples were carried out by Thermomechanical Analyzer (TMA, Setaram® Setsys 16/20) with $5 \mathrm{~g}$ constant load using Helium flow and the heating rate of $10^{\circ} \mathrm{C} / \mathrm{min}$.

The surface characteristics of the sintered phosphate samples agglomerate as well as the unsintered particlesaggregates were studied using Environmental Scanning Electron Microscopy ESEM (XL 30 ESEM-FEG, PHILIPS@).

\section{RESULTS AND DISCUSSION}

\section{III.1. Chemical changes of phosphate ore}

\section{III.1.1. Effect of the temperature on the weight loss}

The effect of temperature on the weight loss $\%$ of samples heated for one hour is illustrated in Figure 2. The weight loss increased continuously, indicating that at each temperature, chemical phenomena take place and lead to gas release. Two zones of weight loss are observed, even if the processes generating the weight losses cannot be easily identified, because of the heterogeneity of the phosphate considered. Nevertheless, the weight loss of $2.5 \%$ in the first zone below $550^{\circ} \mathrm{C}$ can be attributed to the evaporation of water and organic matter. In the second zone, the total weight loss of $5.5 \%$ is observed from 550 to $600^{\circ} \mathrm{C}$ and from 600 to around $1000^{\circ} \mathrm{C}$. 


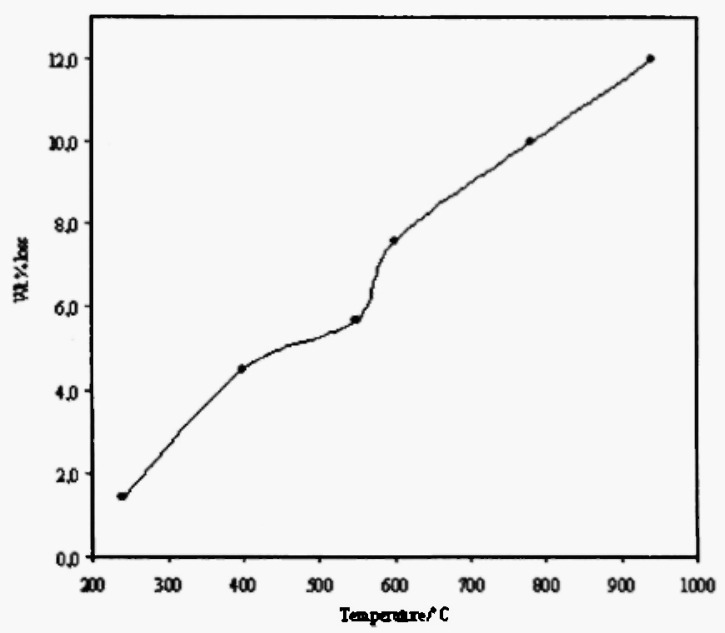

Fig.2: Weight loss (per cent) of phosphate fractions at various temperatures.

Several methods were used to better understand the chemical changes observed.

\section{1.2. Thermal analysis}

DTA and TG studies of the raw material were carried out under. Argon atmosphere from room temperature to $900^{\circ} \mathrm{C}$. As shown in Figure 3, the sample loses weight in two steps. The weight loss from $120^{\circ} \mathrm{C}$ to $550^{\circ} \mathrm{C}$ is due to the removal of water and to the decomposition under argon atmosphere of volatile organic matter (3.7 mass \%).

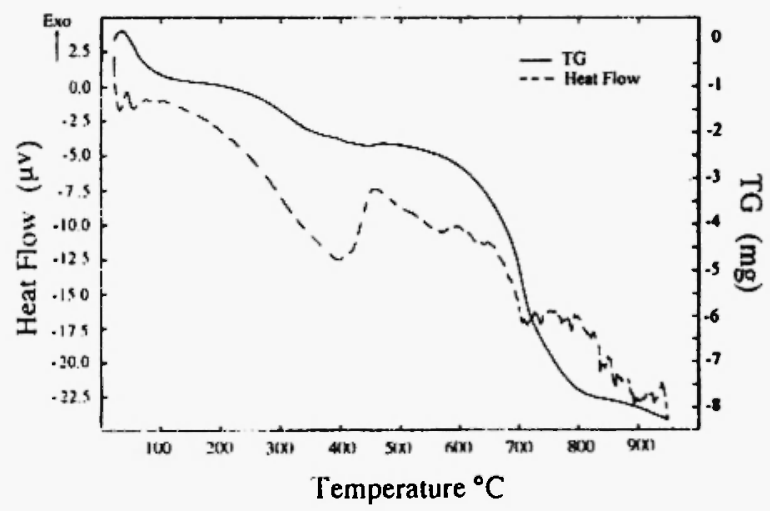

Fig.3: TG and DTA curves of phosphate fraction 125$200 \mu \mathrm{m}$.

As reported in the literature $/ 11 /$, the content of organic matter of some typical phosphate ores ranges between 0.5 to $2.6 \%$. The second mass loss up to $550^{\circ} \mathrm{C}$ corresponds to the decomposition of phosphate gangue (dolomite and calcite) and to the decomposition of $\mathrm{CO}_{2}$ substituted in the apatitic lattice.

Blazy and Samama /19/ reported that the combustion of the remaining of organic matter into calcareous Turkey phosphate occurs between 562 and $784^{\circ} \mathrm{C}$. For the phosphate sample investigated, the weight loss occurring in this range is about $7.0 \%$. The high value of $\mathrm{CO}_{2}$ loss and the content of fuorine of the raw material used mean that the phosphate grains are constituted by carbonato-fluoapatite. This result is in agreement with the X-ray diffraction analysis (Figure 1). The final weight loss given by GTA is about 11 mass $\%$ is in agreement with the value determined using batch experiment under oxygen atmosphere (Figure 2).

As it is possible to observe, the DTA curve (Figure 3) revealed three intensive endothermal effects. The first with a maximum at $400^{\circ} \mathrm{C}$ corresponds to the physical evaporation of water and volatile organic matter. The second between 700 and $800^{\circ} \mathrm{C}$ and the third from 820 to $940^{\circ} \mathrm{C}$ were assigned respectively to the decomposition of dolomite and calcium carbonate (calcite and dolomite). An endothermic peak at $915^{\circ} \mathrm{C}$ attributed to the decarbonatation of the raw phosphate was also observed by Blazy and Samama /19/. However, in this study, this phenomenon is not clearly established.

In addition to DTA-TG, the Controlled Transformation Rate Thermal Analysis (CRTA) was performed to obtain the weight loss of phosphate sample (sample mass : $500-1000 \mathrm{mg}$, heating rate : $10^{\circ} \mathrm{C} / \mathrm{min}$ ). In Figure 4 we have reported the results obtained for the raw sample and those for the heated one at $780^{\circ} \mathrm{C}$.

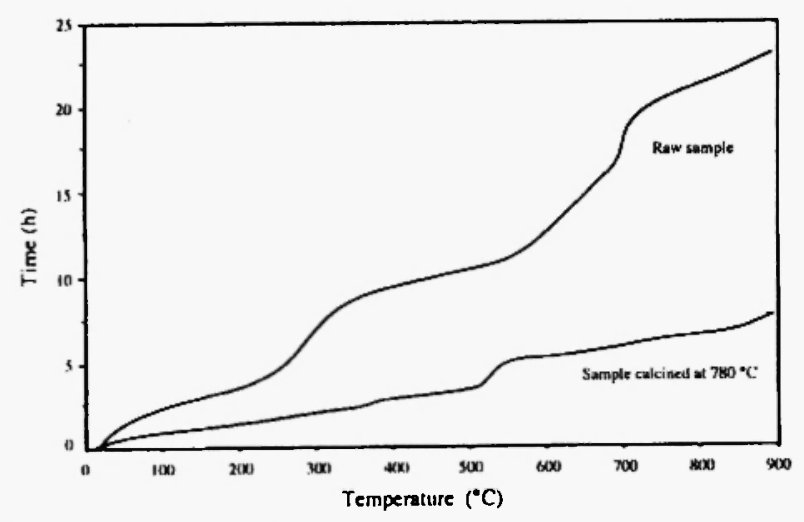

Fig.4: Controlled transformation Rate Thermal Analysis (CRTA) curves of raw sample and sample heated at $780^{\circ} \mathrm{C}$. 
Theoretically, the sample calcined at $780^{\circ} \mathrm{C}$ does not present any appreciable weight loss up to this temperature. A straight line with a slope depending on the experimental condition must be obtained which indicating the heat speed of the apparatus. However, a weight loss is observed in the temperature range 500 to about $600^{\circ} \mathrm{C}$ which probably due to dehydration of $\mathrm{Ca}(\mathrm{OH})_{2}$ observed on the sample heated above $780^{\circ} \mathrm{C}$.

For the raw material, the weight loss observed between 200 and $500^{\circ} \mathrm{C}$ can be attributed to water and the volatile organic matter release. From 550 to $700^{\circ} \mathrm{C}$, a linear increase of the weight loss is observed. At $700^{\circ} \mathrm{C}$, an important weight loss occurs followed by a new slow increase. According to the results of Kaljuvee /6/, the decomposition of $\mathrm{MgCO}_{3}$ occurs between 600 and $780^{\circ} \mathrm{C}$ and the decomposition of $\mathrm{CaCO}_{3}$ takes place between 780 and $900^{\circ} \mathrm{C}$. From the forgoing, we attributed the first weight loss occurring at $620^{\circ} \mathrm{C}$ to the substituted $\mathrm{CO}_{2}$ in the apatitic network, the $\mathrm{CO}_{2}$ dolomitic was released at $700^{\circ} \mathrm{C}$ and the $\mathrm{CO}_{2}$ of calcite was removed after $900^{\circ} \mathrm{C}$.

\section{1.3. Infrared spectra}

Infra-red measurements were also performed to describe some of the chemical changes observed. The infrared spectra of the raw material and samples heated at $240,600,780$ and $940^{\circ} \mathrm{C}$ were recorded and bands have been assigned.

The adsorption peaks at $564,606,960$ and $1088 \mathrm{~cm}^{-1}$ were assigned to $\mathrm{PO}_{4}{ }^{3 \cdot}$ group (Figure 5). This assignment of adsorption bands is in fair agreement with the results reported by different authors $/ 20,21 \%$. These bands were not affected by heat treatment.

However, for the materials heated above $780^{\circ} \mathrm{C}$ the additional bands observed at 866,1426 and $1456 \mathrm{~cm}^{-1}$ disappeared. These peaks assigned to the $\mathrm{C}-\mathrm{O}$ vibration bands characterizing the carbonate-apatite (named francolite). Studying the infrared spectra of sedimentary phosphate rock, Brassens $/ 22 /$ reported similar results. Moreover, the author noted that the peak adsorption observed at $865 \mathrm{~cm}^{-1}$ was attributed to the $\mathrm{CO}_{2 \alpha}$. According to Brassens's study, there are types of $\mathrm{CO}_{2}$, $\mathrm{CO}_{2 \alpha}$ and $\mathrm{CO}_{2 \beta}$, in the francolite network related to the nature of substitution. The $\mathrm{CO}_{2 \alpha}$ is given off between 500 and $790^{\circ} \mathrm{C}$ whereas the $\mathrm{CO}_{2 \beta}$ releases between 800 and $1050^{\circ} \mathrm{C}$.

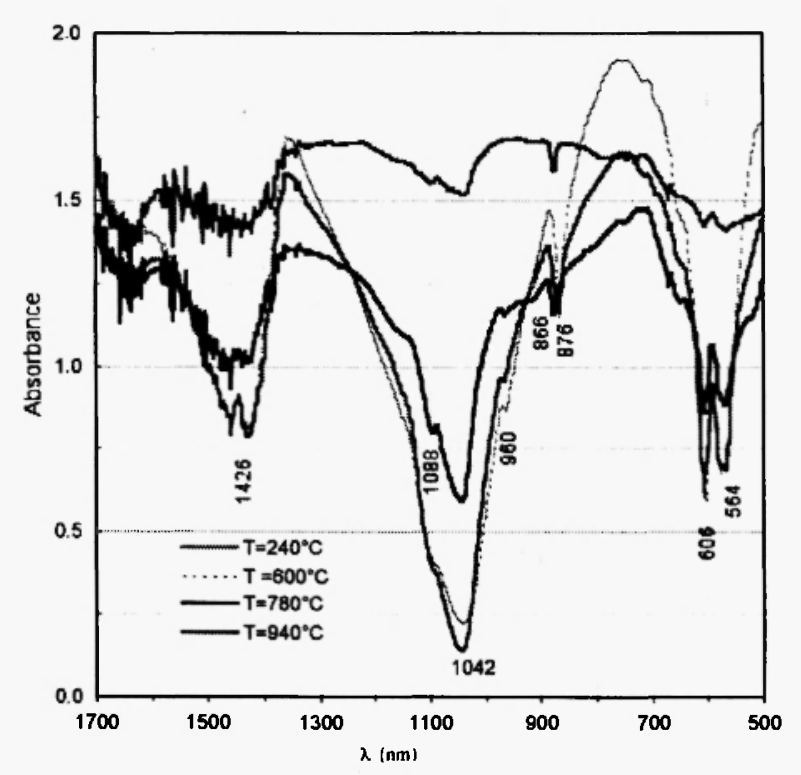

Fig.5: 1R spectra of phosphate particles calcined at different temperatures

The absorption band which appears at about 874 $\mathrm{cm}^{-1}$ for the samples heated above $780^{\circ} \mathrm{C}$ can be attributed to the calcite which results from the action of gaseous $\mathrm{CO}_{2}$ upon the formed $\mathrm{CaO}$. Organic matter in phosphates shows absorptions in the range 2850-2920 $\mathrm{cm}^{-1}$, which are assigned to $\mathrm{C}-\mathrm{H}$ vibrations in $\mathrm{CH}_{2}$ and $\mathrm{CH}_{3}$. Occluded water gives two bands at $3500 \mathrm{~cm}^{-1}$ and $1630 \mathrm{~cm}^{-1}\left(\delta_{\mathrm{OH}}\right)$.

From the results obtained, it is reasonable to assume that the endothermic elimination of water and of volatile organic matter under argon atmosphere occurs below $500^{\circ} \mathrm{C}$ whereas the $\left(\mathrm{CO}_{2 \alpha}\right)$ released from carbonate apatite appears at $620^{\circ} \mathrm{C}$. The endothermic reaction of the dolomite decomposition occurs at $700^{\circ} \mathrm{C}$ and finally an endothermic peak of decarbonation was observed up to $900^{\circ} \mathrm{C}$.

\section{III.2. Structural changes of phosphate ore}

\section{III.2.1. Evolution of the porous properties of phosphate during heat treatment}

Absolute density, also called true density, was measured for samples after heating at $240,400,550$, 600,780 and $940^{\circ} \mathrm{C}$. The absolute density is obtained when the volume of Heiium measured excludes the pores within the sample material. The percent porosity 
of solid can be calculated as follows:

$$
\text { Percent porosity }=\left(1-\frac{\rho_{\mathrm{b}}}{\rho_{\mathrm{a}}}\right) * 100
$$

where $\rho_{\mathrm{b}}$ and $\rho_{\mathrm{a}}$ were the bulk and absolute density of the sample.

These two density values were derivable from a mercury test. Contrary to the true density the bulk one includes the pores within the material. The phosphate ore used in this work presents a true density equal to $2.970{\mathrm{~g} . \mathrm{cm}^{-3}}^{-3}$ and a percent porosity determined using mercury porosimetry equal to $31 \%$.

Figure 6 shows that helium density passes through a minimum when temperature of calcination reaches $600^{\circ} \mathrm{C}$. Our values are less than the data reported by Janikowski $123 \%$. The bulk density of different natural phosphate samples reported by the authors is in the range of 2.035 to $2.800 \mathrm{~g} . \mathrm{cm}^{-3}$ whereas the absolute density is in the range of 3.16 to $4.70 \mathrm{~g} \cdot \mathrm{cm}^{-3}$. No correlation was found between density and surface area.

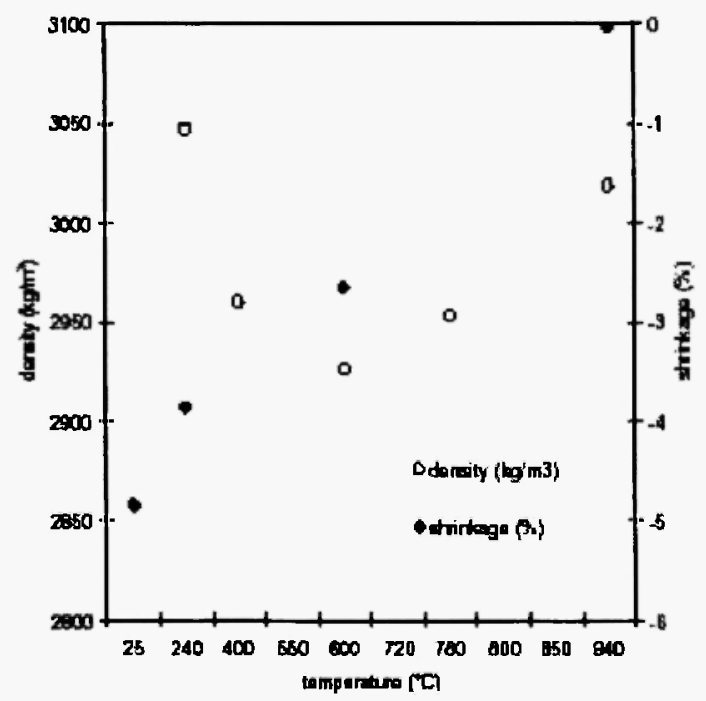

Fig. 6: True density of phosphate (fraction 125$200 \mu \mathrm{m})$ at various temperatures

The decrease in the true density of samples after heating at different temperatures below $600^{\circ} \mathrm{C}$, can be related to the removal of water and volatile organic compounds. In this region, when mass loss is occurring intensively, the material volume will change slightly involving the decrease of the ratio mass by volume. Up to $600^{\circ} \mathrm{C}$, we assist to the densification phenomenon. According to Ben Ayed $/ 14 /$, the Fap densification began at $700^{\circ} \mathrm{C}$. The decrease and the increase of the material density can be correlated to the dilatometeric behavior.

The nitrogen adsorption and desorption isotherms for the raw material and the products after heating at 600 and $940^{\circ} \mathrm{C}$ are shown in Figure 7. All samples exhibit a type $\mathrm{H} 3$ isotherm based upon the classification of International Union of Pure Applied Chemistry (IUPAC). This hysteresis loop with a vertical adsorption branch at a medium pressure indicates the presence of pores which have narrow short opening. Moreover, at low relative pressure $\left(\mathrm{p} / \mathrm{p}_{0}\right)$ less than 0.42 (below this value adsorption and desorption curve were superimposed), the slopes were different. These latter were correlated to the specific surface area which was calculated by the BET method. However pore size was calculated by the BJH method using the desorption isotherm.

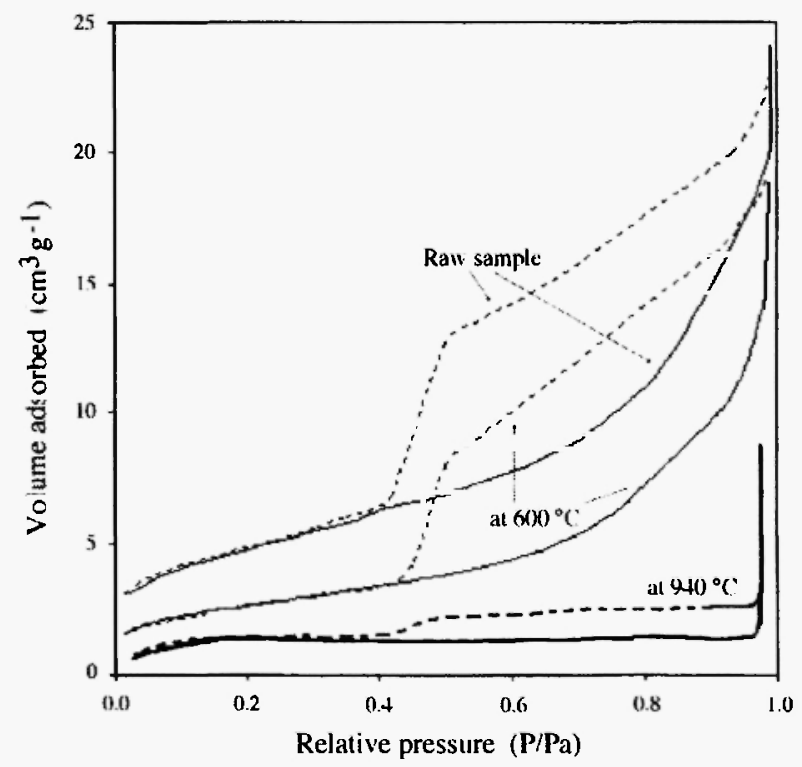

Fig. 7 : Sieved fraction 125-200 $\mu \mathrm{m}$ : Adsorption/ desorption isotherms of phosphate ores before and after heat treatment at 600 and $940^{\circ} \mathrm{C}$. (solid lines: adsorption; dotted line: desorption)

The specific surface area, the pore volume and the shrinkage $\%$ are most reliable indicators of the sintering event because their evolutions are linked to the 
Table 2

Porous properties of calcined samples

\begin{tabular}{|c|c|c|c|c|}
\hline $\begin{array}{l}\text { Temperature of calcination } \\
\qquad\left({ }^{\circ} \mathrm{C}\right)\end{array}$ & $\begin{array}{c}\text { J }_{\mathrm{BET}} \\
\left(\mathrm{m}^{2} \cdot \mathrm{g}^{-1}\right)\end{array}$ & $\begin{array}{l}\text { Pore Volume } \\
\left(10^{3} \mathrm{ml}^{-\mathrm{g}^{-1}}\right)\end{array}$ & $\begin{array}{l}\text { Pore diameter } D_{p} \\
\qquad(n m)\end{array}$ & Shrinkage (\%) \\
\hline As- received & 16.61 & 31.6 & 7.6 & -4.838 \\
\hline 240 & 13.82 & 29.6 & 8.5 & -3.861 \\
\hline 550 & 9.19 & 27.7 & 12.1 & \\
\hline 600 & 7.82 & 25.0 & 12.7 & -2.648 \\
\hline 940 & 0.81 & 2.3 & 6.9 & -0.030 \\
\hline
\end{tabular}

mechanism of the sintering and also that these parameters are easily and reliably measured. This paragraph is focused on the effect of calcination temperature and chemical changes observed on the structural behavior of the phosphate ore.

Changes in $\mathrm{S}_{\mathrm{BET}}$, pore volume and the linear shrinkage (\%) are listed in Table 2 . The specific surface area starts to decline at $240^{\circ} \mathrm{C}$ and reach a minimum at $940^{\circ} \mathrm{C}$ (Figure 8). Many works are available in the literature on the effect of the calcination in the surface area reduction of hydroxyapatite powders $/ 14,15,16,23$. In most cases the reduction of specific surface area is correlated with the reduction of porosity and the densification (increasing of the absolute linear shrinkage $\%$ ), as shown in Table 2.

Studying the calcination and the sintering of calcium phosphate apatites with variable $(\mathrm{Ca} / \mathrm{P})$ atomic ratio, the authors $/ 15,17 /$ noted different domains of surface reduction versus temperature corresponding to different reaction rate. This suggests that the mechanism of loss of specific surface area, pore volume and densification may be changing with the temperature.

In all cases, the low surface decrease, observed below $500^{\circ} \mathrm{C}$, corresponds to the removal of the matter according to the gaseous transfer and external diffusion. Above this temperature, a drastic decline of surface area attributed to the diffusion of matter between bounded grains At higher temperature up to $780^{\circ} \mathrm{C}$, the rate of surface area decline slowed down. The kinetic modeling

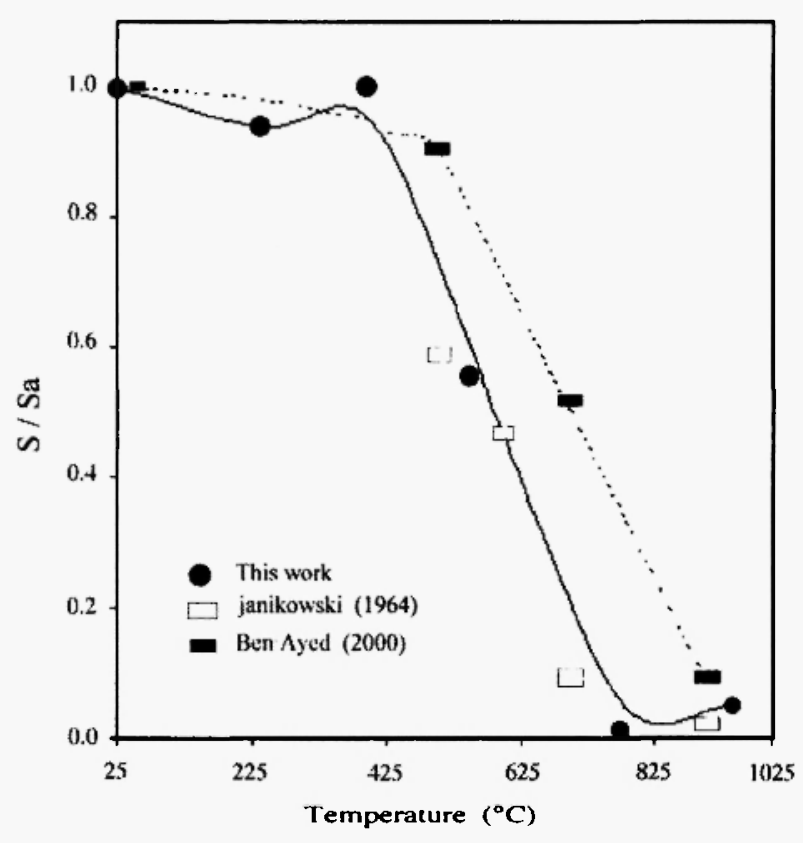

Fig.8: Normalised surface area of phosphate samples after heat treatment ( fraction size 125-200 $\mu \mathrm{m}$ and Ihour holding time of heat treatment).

of surface area reduction versus sintering or thermal decomposition temperature of solids was studied by several authors $/ 14,17,24-16 /$. To argue their conclusions about the surface area decrease, Raynaud et al. $/ 15 /$ completed their study by a dilatometric investigation.

In this study, the linear shrinkage \% was measured 
for the raw material and samples after heating at 240 , 600,780 and $940^{\circ} \mathrm{C}$. The results are shown in Figure 9 and Table 2. The raw material expanded in the temperature range up to $1000^{\circ} \mathrm{C}$. This phenomenon can be related to the high $\mathrm{CO}_{2}$ content in phosphate rock. The calcium phosphate apatites have a thermal expansion coefficient ranging between $1210^{-6}$ to $1610^{-6}$ $\mathrm{K}^{-1}$. All samples except that heated at $940^{\circ} \mathrm{C}$ present a thermal expansion in the temperature range up to about $720^{\circ} \mathrm{C}$. This is probably due to the removal of volatile organic matter and the dolomite decomposition However, the shrinkage began from about $720^{\circ} \mathrm{C}$ until $900^{\circ} \mathrm{C}$. In this domain, similar behavior was already described in other synthetic calcium phosphate compounds. Especially, densification mechanism of synthetic fluorapatite occurs in this temperature range. On the other hand, the surface area reduction was attributed to both particle coalescence and sintering. These results were confirmed by scanning electron microscopy observations.

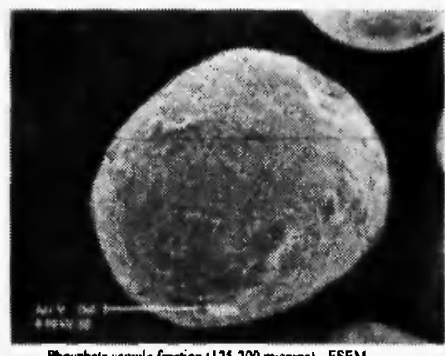

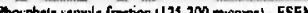

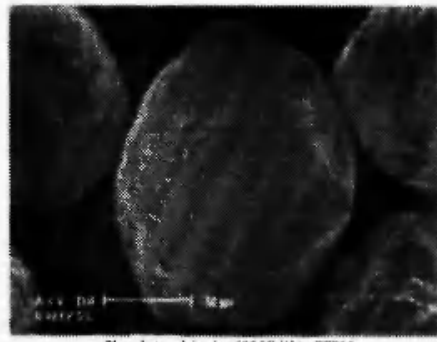

Prosphate calined $a 600^{\circ} \mathrm{C}(\mathrm{l})$ ) - ESEM
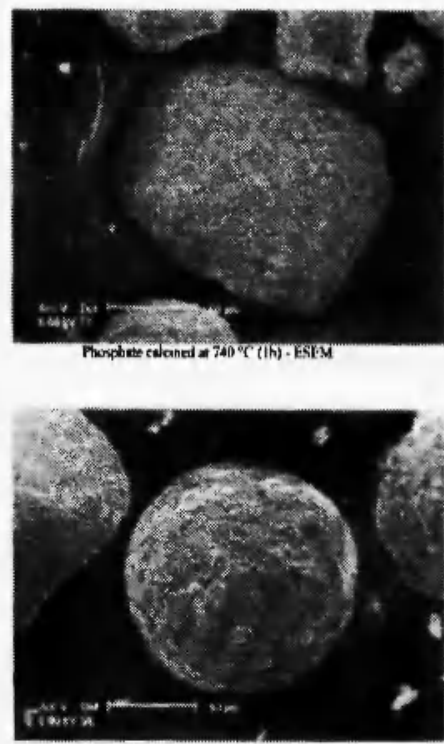

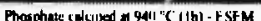
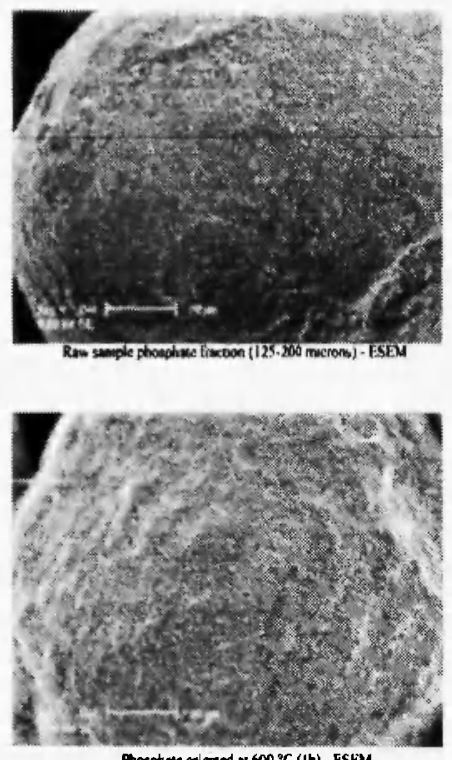

Phosphatec coldened as $600^{\circ} \mathrm{C}(\mathrm{h})$ - ESEM

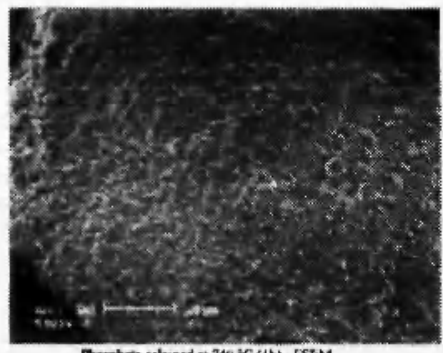

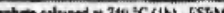

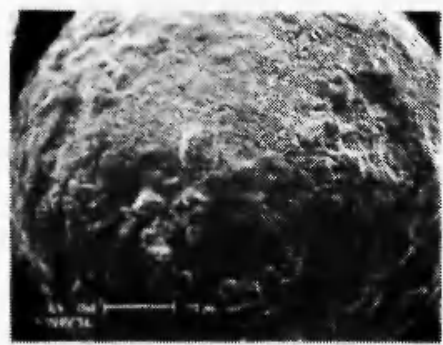

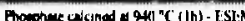

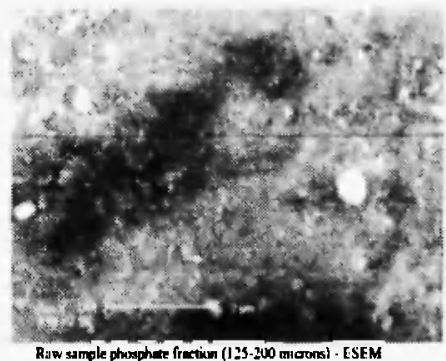

Riw sample phosphate frretive (135-2100 miconsi) - ESEM
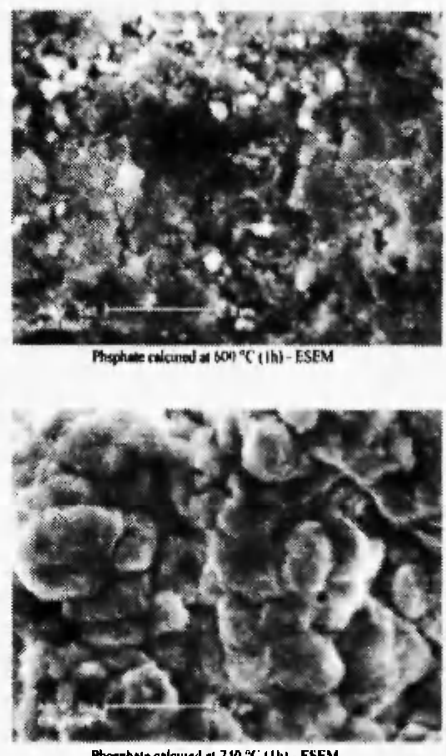

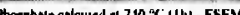

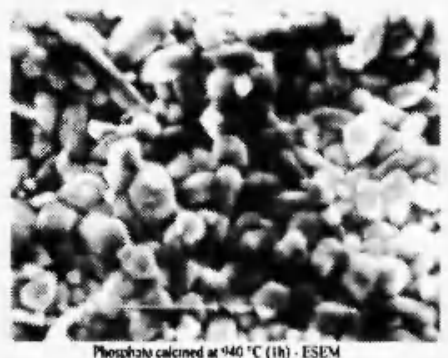

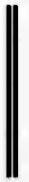

a) Raw sample

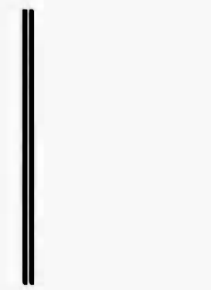

b) Phosphate at $600^{\circ} \mathrm{C}$

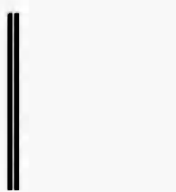

c) Phosphate at $740^{\circ} \mathrm{C}$

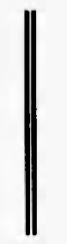

d) Phosphate at $940^{\circ} \mathrm{C}$

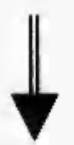

Fig.9: ESEM. micrographs of phosphate samples heated for 1 hour at: (a) Raw sample as received, (b) calcined at $600^{\circ} \mathrm{C},(\mathrm{c})$ calcined at $740^{\circ} \mathrm{C},(\mathrm{d})$ calcined at $940^{\circ} \mathrm{C}$ 


\section{III.2.2. The ESEM observations}

The morphology of phosphate particles after different calcination treatments is presented in Figure 9. It is shown that the shape of phosphate particles is not affected after heating at 600,740 and $940{ }^{\circ} \mathrm{C}$. The phosphate particles do not disintegrate during heating.

According to the SEM photographs of raw phosphate rock, given by OSER et al. $27 /$, the Turkey phosphate rock presents two parts, the dark gray one being defined as $\mathrm{CaCO} 3$. No distinguishing parts were observed in the Tunisian phosphate investigated.

The microstructure observation (enlarged photographs) of calcined materials showed significant differences depending on the temperature of calcinations. Up to $780^{\circ} \mathrm{C}$, the microstructure was close to that of pure Fap (crystallites appear in a rod like form). At $940^{\circ} \mathrm{C}$ (as seen in the enlarged photograph), the calcined particles have a homogeneous microstructure with an average grain size of about $\mathrm{I} \mu \mathrm{m}$. According to Kaljuvee et al.'s /6/ study, the optimum temperature interval. for calcination of natural phosphorites is $850-950^{\circ} \mathrm{C}$ and the recommended heating time not more than 5-10 minutes. Below 600 ${ }^{\circ} \mathrm{C}$, samples presented more smooth surfaces with little cracks and crystallites appear in a flake-like form.

When temperature increases the grain growth becomes exaggerated according to the thermal expansion of Fap and the decrease of specific surface area can be attributed to the grain growth.

\section{CONCLUSIONS AND RECOMMENDATIONS}

Detailed experimental analyses of chemical and physical changes of phosphate ore are presented. On the basis of the present study, the following conclusions can be drawn :

- The main minerals of phosphate particles investigated are carbonate fluorapatite, fluorapatite, calcite and dolomite which are dispersed heterogeneously in the grain,

- The water of constitution and volatile matter release below $500^{\circ} \mathrm{C}$ whereas the $\mathrm{CO}_{2 \alpha}$ substituted in the apatitic lattice leaves off up to $620^{\circ} \mathrm{C}$. In this temperature range, from room temperature until $600^{\circ} \mathrm{C}$, the true density decreases and the grain expanses,

- The dolomite decomposition occurs at about $700^{\circ} \mathrm{C}$ and the calcite in phosphate decomposes above $900^{\circ} \mathrm{C}$. In this domain, the densification occurs and the particles shrank,

- The decreases in the specific surface area and in the pore volume combined with the increasing of the shrinkage percentage confirm the sintering of the ore phosphate during the calcination,

- The ESEM observations reveal the rounding of particles below $600^{\circ} \mathrm{C}$ and the formation of necks up to this temperature.

- More investigation concerning the reactivity of heated phosphate particles are required for better understanding. of the influence of chemical and physical properties on the acidic phosphate rate leaching.

\section{REFERENCES}

1. Processing and Equipment for Beneficiation of Calcareous Phosphate Ores. Fr. pat., 2, 486, 924 (1982).

2. Beneficiation of Phosphate Ores. Fr. pat., 2, 554, 300 (1984).

3. A.Z.M. Abouzied, I.S. El Jallad, M.K. Orphy, Min. Sci. Eng. 12, 73-83 (1980).

4. D. Kumar, Chem. Eng. Technol., 52 (9), 736-740 (1980).

5. P. Becker, Phosphate and Phosphoric Acid, Marcel Dekker Inc, Chapter 2, Process review, 35 140 (1989)

6. T.B. Kaljuvee, R.O. Kuusik, M. Viederma, Int. J. Miner. Proc., 43, 113-121 (1995).

7. Zafar, M.M. Anwar, D.W. Pritchard, 1995, Int. J. Miner. Proc. 43, 123-131 (1995)

8. J.R. Lehr, S.S. Hsieh, Beneficiation of High Carbonate Ores, U.S. Pat. 4, 287, 053 (1981).

9. J. Fava, A. Lambert, J.P. Tognet, J.M.R. Lafosse, B.J.M. Robet, Procede d'enrichissement d'un minerai à gangue carbonatee, notamment d'un minerai de phosphate, Fr. pat. Appl., 81, 20558 (1981).

10. P. Blazy, E.A. Jdid, C.R. Acad. Sci., Paris, (Ila) 321, 287-294 (1995). 
11. A.V. Slack, Phosphoric Acid Part II, Marcel Dekker, Inc, New York (1968).

12. A. Ababou, M. Bernache-Assollant, Heughebaert., Ann. Chim. Fr., 19, 165-175 (1994).

13. F. Ben Ayed, K. Bouaziz, K. Bouzouita, Journal of European Ceramic Society, 20, 1069-1076 (2000).

14. F. Ben Ayed, K. Bouaziz, K. Bouzouita, Journal of Allows and Compounds, 322, 238-245 (2001).

15. S. Raynaud, E. Champion, D. Bernache-Assolant, Biomaterials (23), 1073-1080 (2002).

16. A. Nzihou, S. Bailliez, High Temp. Mater. Proc., 21 (5), 281-295 (2002).

17. S. Bailliez, A. Nzihou, Chem. Eng. J., 98, 141-152 (2004).

18. D.E. Evangelos, T.C. Vaimakis, E.M. Papamicheal, Journal of colloid and interface Science, 201, 164-171 (1998).

19. P. Blazy, J.C. Samama, C.R. Acad Sci., Paris, 333, 271-276 (2001).

20. C.B. Baddiel, E.E. Berry, Spectrochimica Acta, 22,
1407-1416 (1966).

21. V.M. Bhatnagar, Bull. Soc. Chim., Fr., 1771-1773 (1968).

22. A. Brassens, C.R. Acad. Sci., Paris., 280 (C), 879881 (1975).

23. M. Janikowski, N. Robinson, W.F. Sheldrick, Theory and Experimental Technique, Fert. Soc., 81, 3-51 (1964).

24. W.G. Schaffer, C.Z. Morgan, J.N. Wilson, J. Phys. Chem., 61, 714-722 (1975).

25. D. Nicholson, Trans. Faraday Soc., 61-509, 990998 (1965).

26. R.M. German, Z.A. Munir, J. Am. Ceram. Soc., 59, 379-84 (1976).

27. A.K. Özer, M. Gülabo lu, S. Bayrakçeken, Ind. Eng. Chem. Res. 39, 679-683 (2000).

28. F. Ben Brahim, A. Mgaidi, M. El Maoui, Can. J. Chem. Eng. 75, 759-764 (1997).

29. F. Peters, K. Schwarz, M. Epple, Thermochimica Acta., 36, 131-138 (2000). 